praksis møte personer som sliter med søvnløshet/insomni som defineres ved en av følgende: Forlenget innsovningstid på over 30 minutter, avbrutt søvn med til sammen over 45 minutter med våkenhet i løpet av søvnperioden eller for tidlig oppvåkning når søvnperioden er mindre enn seks timer eller når det er over 30 minutter mellom aktuelt oppvåkningstidspunkt og ønsket oppvåkningstidspunkt. Et medisinsk problem oppstår først når det avvikende søvnmønsteret gir symptomer på dagtid.

I de innledende kapitlene går forfatterne igjennom statistikk, definisjoner/inndelinger, beskrivelse av kjønnsforskjeller, utvikling av søvnbehov med økende alder, årsaker og medisinske konsekvenser av søvnmangel. Dette gjøres kortfattet og presist.

Forfatterne understreker at bruk av søvndagbok før, under og etter behandlingen er et sentralt verktøy som også bidrar til å gi pasienten mer selvinnsikt.

Spesielt nyttig er gjennomgangen av ikke-medikamentelle behandlingsprinsipper hvor søvnrestriksjon og stimuluskontroll står sentralt. Avspenningsteknikker, bruk av melatonin og lysbehandling gjennomgås. Selv om ikke-medikamentell behandling er å foretrekke og har best langtidsresultater, poengterer forfatterne at medikamentell behandling noen ganger kan være aktuelt $i$ en begrenset periode og da i kombinasjon med andre tiltak (søvnhygiene, stimuluskontroll, avspenningsteknikker etc.). Viktige problemstillinger ved medikamentell behandling tas opp: Når kan sovemidler brukes? Når skal sovemidler ikke brukes? Ved hvilke tilstander skal man være spesielt forsiktig med bruk av sovemidler?

Mot slutten av fremstillingen er det et kapittel med spørsmål og svar fra egenerfarte konsultasjoner som også fungerer som en repetisjon av de sentrale temaene som tidligere er gjennomgått. I det siste kapitlet forklares sentrale ord og uttrykk i somnologien, noe som vil være spesielt nyttig for ikke-medisinere.

Et tradisjonelt indeksregister bakerst savnes. Jeg registrerer også at referanseoversikten bare inneholder to referanser fra tiden etter 2001, hvorav den ene er forfatternes egen bok Søvn og søvnforstyrrelser fra 2005. På tross av disse mindre ankepunkter vil jeg anbefale boken til sykehusleger og fastleger som ønsker et større repertoar å spille på i møtet med «den søvnløse pasient».

Geir D. Slapø

Oslo Nevrologipraksis

\footnotetext{
Litteratur

1. Heier MS, Wolland AM. Søvn og søvnforstyrrelser. Oslo: Cappelen, 2005.

2. Heier MS, Wolland AM. Barn og søvn. Oslo: Cappelen akademisk, 200\%.
}

\section{Konkret samtalehjelp med barneperspektiv}

Eide G, Rhode R

\section{Sammen så det hjelper}

Metoder i samtaler med barn, ungdom og familier. 235 s. tab, ill. Bergen: Fagbokforlaget, 2009. Pris NOK 338

ISBN 978-82-450-0789-3

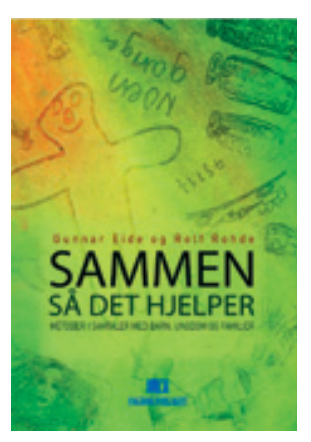

Barn uttrykker seg gjennom ord, men også gjennom lek, tegning og annen aktivitet. Etter hvert som det kommunale hjelpetilbudet til barn og familier bygges ut, vil stadig flere trenge konkrete verktøy for å samtale med barn om vanskelige temaer. Sammen så det hjelper er en metodebok innen helse-og sosialfagene som gir konkret veiledning til fagfolk som arbeider med familier der noen sliter, men den kan også være nyttig for andre som til daglig har med barn å gjøre.

Fremstillingen er delt inn i 11 kapitler, der det første kapittelet er mer generell teori, mens de øvrige beskriver ulike metoder for samtale og samvær med barn og familier. Hvert kapittel innholder historien til ett eller flere barn som er blitt hjulpet med den beskrevne metoden. I tillegg til beskrivelse av de enkelte metodene beskrives også hensikten med akkurat denne metoden - du må velge tilnærmingsmåte både etter det enkelte barn og hva du ønsker å få frem. Forfatterne er erfarne familieterapeuter og benytter seg mye av konkret materiale, slik som livets elv, samtaletegninger, tenkespørsmål osv. Metodene, som til del springer ut fra forfatternes egne kliniske erfaringer, er illustrert både med samtalebilder, utformet av billedkunstner Tove Krogh, og tegninger til den enkelte metode, som utgjør en metodebok. Forlaget har dessverre ikke passet på at hver enkelt tegning kommer på samme side som metoden den illustrerer, og det gir et noe uryddig inntrykk. I tillegg til metoder som kan tas i bruk direkte, beskrives også den mye brukte Marte-Meo-metoden, som bruker videoopptak av små samspillssituasjoner for å støtte foreldres mestring. Denne metoden kan ikke tas i bruk uten særskilt opplæring, men prinsippene den bygger på er allmenngyldige og derfor nyttig lesing.

$\AA$ være sammen så det hjelper, er lettere sagt enn gjort. Samtaler med barn kan åpne eller lukke, og ikke alle er til hjelp. Forfatterne understreker tydelig barneperspektivet i sin tilnærming til familier, også der foreldre er psykisk syke. Denne bokens styrke er at den er så tydelig og konkret. Her for- telles ikke bare hva, men også hvordan. Både samtalebildene og metodeboken deles raust med leseren, som kan laste dem ned fra nettet til bruk i egen praksis (1). På den måten blir boken en ekte praksisveileder som vil være til nytte for de mange som skal ha samtaler med barn og foreldre om følelsesmessig vanskelige temaer.

Jannike Engelstad Snoek

Klinikk for psykisk helse barn og unge

Oslo universitetssykehus, Ullevål

\section{Litteratur}

1. Fagbokforlaget. www.fagbokforlaget.no/sammen (25.1.2010).

\section{God selvhjelpsbok}

Cramer G, Furuholmen D.

Våg mer!

En bedre hverdag med psykologisk trening

192 s, ill. 2. utg. Oslo: Kom forlag, 2008.

Pris NOK 199

ISBN 978-82-92496-57-2

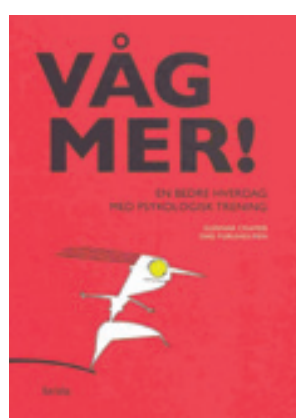

Gunnar Cramer og Dag Furuholmen er psykiatere som har bred klinisk erfaring i tillegg til at de har drevet kurs i personlig utvikling i mange år. Med denne boken har de lyktes med å integrere klinisk erfaring og pedagogikk fra kursene sine på en særdeles god måte.

Våg mer! er en god selvhjelpsbok som brukt seriøst kan hjelpe leseren til å endre tanker, atferd og mestringsnivå. Den er ærlig og redelig og det foreslås ingen snarvei til et bedre liv. Tvert imot sammenliknes psykologisk trening med fysisk trening. Du må gå inn for saken, trene ofte nok i økende doser for at effekten skal komme. Men følger du opplegget, kan du regne med resultater.

Til forskjell fra en del andre bøker i samme sjanger er Våg mer! ikke så overpedagogisk at leseren opplever seg som en grunnskoleelev. Den lover heller ingen "quick fix» som er så vanlig i denne type litteratur, men skisserer et systematisk treningsopplegg som krever både innsats og motivasjon av leseren, ingredienser som er nødvendige for å kunne oppnå endring.

Boken er gjennomillustrert med morsomme tegninger av Iben Sandemose som gir den en tiltalende form. Den er bygd opp med noter etter hvert kapittel som kan leses parallelt med hver noteangivelse, eller som et mer teoretisk avsnitt etter hvert kapittel. 
Boken formidler psykologisk allmennkunnskap, er praktisk orientert og gjennom dette avmystifiseres psykologisk arbeid på en god måte. Det forebyggende perspektivet er inkorporert i tillegg til selve treningselementene. Etter min mening kan denne boken anvendes av alle lesende mennesker som er motivert til å få en bedret psykologisk mestringsevne eller bedret selvfølelse. Jeg vil også anbefale den til helsepersonell og kolleger innen psykiatrien, i tillegg til allmennpraktikere.

\section{Synnøve Bratlie}

Dr. Bratlies spesialistpraksis

Oslo

\section{Industriens angrep på folkehelsen i USA}

Michaels D.

\section{Doubt is their product}

How industry's assault on science threatens your health. 372 s. Oxford: Oxford University Press, 2008. Pris GBP 18 ISBN 978-0-19-530067-3

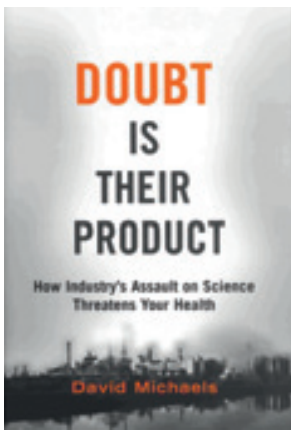

Dette er en bemerkelsesverdig bok. Den handler om hvordan storindustrien i USA har manipulert vitenskapelige data, produsert egne data og publisert dem i vennligsinnede, til dels egenkontrollerte tids-

skrifter med fagfellevurdering (1), og gjennom dette arbeidet til dels oppnådd å lamme deler av tilsynsetatene i USA. Spesielt gjelder det OSHA, som tilsvarer vårt arbeidstilsyn, men også EPA (som tilsvarer Statens forurensningstilsyn) og Food and Drug Administration (FDA). Tittelen henspiller på et utsagn fra et medlem av tobakkslobbyen: «Doubt is our product since it is the best means of competing with the «body of fact» that exists in the mind of the general public. It is also the means of establishing a controversy.»

På vaskeseddelen er det gjengitt et utsagn fra Donald Kennedy, sjefredaktør i Science som sier at boken «gir en livlig og overbevisende framstilling av hvordan den ene folkehelseetaten etter den andre er blitt blokkert. Teknikkene som først ble brukt for å berolige oss om tobakkens virkninger er seinere blitt tilpasset for å berolige oss om asbest, bly, vinylklorid - og risikoen for arbeidere i atomindustrien. Dette siste er et område hvor dr. Michaels erfaring som statssekretær i energidepartementet ga ham inngående kunnskap. Og hvis du er bekymret for miljøet, fortsett med det fordi det samme programmet er i gang der» (min oversettelse).

I tillegg til dette blir flere andre områder omtalt, bl.a. passiv røyking, krom, popkornlunge og narkotika. Forfatteren har begrenset seg til omtale av forhold han selv har vært direkte involvert i, som forsker eller byråkrat.

Da jeg leste boken, var jeg i ferd med å avslutte en rapport om kjemisk helserisiko i olje- og gassindustrien. Det er dokumentert at forskningsresultater i deler av denne industrien varierer systematisk med om forskerne er tilknyttet industrien eller ikke $(2,3)$. En påminnelse om industriens innflytelse fikk vi i Tidsskriftet nr. 21/2009 hvor Helge Waldum fortalte at han ble overrasket over den sterke industritilknytningen til enkelte andre medlemmer i en nordamerikansk komité han deltok i (4). Det kom også nettopp frem at flere av medlemmene i gruppen bak WHOs anbefalinger angående svineinfluensaepidemien er tilknyttet medisinalindustrien. Det er selvfølgelig legitimt å fremme egne interesser, det er noen av metodene vi må ta avstand fra, skriver Michaels, og trekker blant mye annet frem at arbeidet som drives av uavhengige forskere blir betegnet som «junk science» av industrilobbyen, mens det den selv bedrivern betegnes som «sound science». Orwell ville kjent seg igjen.

I USA fikk industriens bestrebelser god støtte under president George W. Bush, bl.a. ved at i flere komiteer som vurderer mulige helsemessige konsekvenser av miljøforurensninger ble uavhengige vitenskapsfolk byttet ut med representanter for industrien. Dette kan det kanskje bli en slutt på under president Obama fordi i sommer nominerte han Michaels som ny sjef for OSHA. Dette har som ventet møtt sterk motstand fra industrien, men også støtte, f.eks. i en leder i New York Times 6.8. 2009 (5).

Av de 372 sidene er 80 litteraturreferanser, for med en så formidabel motstander har forfatteren ikke råd til å publisere noe som ikke kan dokumenteres.

Boken skulle være av interesse for alle samfunnsinteresserte og spesielt for lederne av tilsynsetater som Arbeidstilsynet, Statens forurensningstilsyn, Mattilsynet, Petroleumstilsynet og Folkehelseinstituttet.

PS: Senatet i USA godkjente Michaels som ny sjef for OSHA like før jul 2009.

\section{Håkon Lasse Leira}

Arbeidsmedisinsk avdeling

St. Olavs hospital

\section{Litteratur}

1. Expression of concern about absence of editorial independence of the journal Regulatory Toxicology and Pharmacology www.cspinet.org/new/pdf/ final_letter_academic_press_rtp.pdf (29.11.2009).

2. Egilman D, Scout, Kol L et al. Manipulated data in Shell's Benzene Historical Exposure Study. Int J Occup Environ Health 2007: 13: 222-32.

3. Infante PF. The past suppression of industry know ledge of the toxicity of benzene to humans and potential bias in future benzene research. Int J Occup Environ Health 2006; 12: 268-72.

4. Waldum HL. Protonpumpehemmere bør ikke selges reseptfritt. Tidsskr Nor Legeforen 2009 129: 2263.

5. A champion for workers' safety. New York Times 6.8. 2009

\section{Praktisk om pasientsikkerhet - fra teori til verktøykasse}

Reynard J, Reynolds J, Stevenson P.

Practical patient safety

318 s, tab, ill. Oxford: Oxford University Press, 2009. Pris GBP 30

ISBN 978-0-19-923993-1

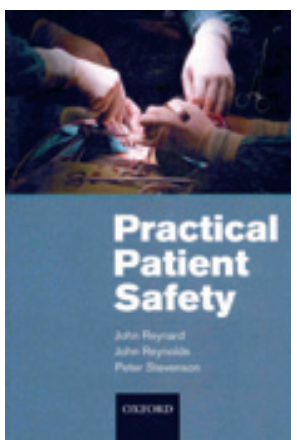

Dette er en viktig bok som kan anbefales til de fleste som arbeider innen helsesektoren. Selv om den er skrevet av to kirurger og en flypilot, vil innholdet være gyldig på tvers av disipliner.

Forfatternes hovedmål er å opplyse leseren om hvordan feil oppstår og hvordan de forebygges, hovedsakelig gjennom bevisstgjøring av feil og nestenfeil og slik stimulere til holdningsendringer. Dette er de praktiske aspektene - de lanserer ikke fancy utstyr, dataprogrammer, dyre maskinløsninger eller tunge kursprogrammer som skal sikre trygge pasientforløp i helsevesenet. Hovedanliggende er deg som individuell lege/sykepleier og hva du kan gjøre ved å endre holdninger. Den systematiske oppbygningen gjør at man får innsikt $\mathrm{i}$ «feilbehandling» som et problem, på hvilke områder og i hvilke situasjoner den gjerne og ofte forekommer, samt en del tips og råd om hvordan man kan forebygge, redusere og forhindre feil eller uønskede hendelser i helsevesenet.

I de to første kapitlene omtales kliniske feil og hva disse består i - det meste av bakgrunnstoffet er hentet fra USA og Storbritannia. Kapittel 3 trekker paralleller til organisasjoner og aktiviteter som baserer seg på en veldig lav forekomst av feil - slik som i fly- og togtransport. I kapittel 4 presenteres 20 ulike kliniske feil fra virkeligheten, så som «feil pasient», «feil blod», «feil-side kirurgi», «feilmedisinering», og «feil ved tretthet/fatigue» med fatale eller varige men for pasientene. Disse læreeksemplene trekkes frem i de resterende kapitlene, og sånn sett forutsettes det at man husker de ulike hendelsene når man leser resterende deler av boken. Kapitlene 5-8 tar for seg håndtering av feil, kommunika- 